\title{
The role of biological adhesive and suture material on rabbit hepatic injury ${ }^{1}$
}

\author{
O papel da cola biológica e do fio de sutura na lesão hepática em coelhos
}

\author{
Murched Omar Taha ${ }^{2}$ Karen De Rosa ${ }^{3}$, Djalma José Fagundes ${ }^{4}$ \\ 1. Research from PIBIC (Project Institutional Program of Grants for Scientific Initiation - CNPq) and Post-graduation Program in Surgery \\ and Experimentation of Federal University of São Paulo (UNIFESP), Brazil. \\ 2. Affiliated Professor of Surgery Department and Professor of Post-graduation Program in Surgery and Experimentation, UNIFESP, Brazil. \\ 3. Medical Student of UNIFESP, Brazil. \\ 4. Associate Professor of Surgery Department and Coordinator of Post-graduation Program in Surgery and Experimentation, UNIFESP, Brazil.
}

\begin{abstract}
Purpose: To evaluate the performance of fibrin adhesive and absorbable suture thread in the repairing of hepatic injures in rabbits. Methods: New Zealand albino rabbits $(\mathrm{n}=16)$, males and females, from 5 to 6 months old, average weight of $2500 \mathrm{~g}$, were distributed randomly in Group A (n-8) - biological adhesive and Group B (n=8) - suture thread. After anesthesia with acepromazine $(1 \mathrm{mg} / \mathrm{Kg})$, ketamine $(50 \mathrm{mg} / \mathrm{Kg})$ and fentanyl $\mathrm{EV}(0,5 \mathrm{ml} / \mathrm{Kg})$, it was performed a supra-umbilical median laparotomy, the median hepatic lobe was isolated and subjected to severe standardized incision. In the group B the incision edges were sutured with simple 4-0 catgut, in separated stitches. It was evaluated the total time of the procedure, the hemostasis time and hemorrhage volume. In the $21^{\text {st }}$ post-operative day it was evaluated the presence of adherences and signs of infection in the abdominal cavity, and it was followed by the resection of the median hepatic lobe for the histological evaluation. Results: The calculated mean and standard deviation showed that the procedure time, hemostasis time and bleeding amount were significantly smaller in the group of animals subjected to the use of fibrin adhesive. The surgical abdominal incision was significantly more extensive in the animals of the suture group (average of 6,8 cm) in relation to the adhesive group (average of 3,8), as well as the number of occurrences of abscesses. The adherence of the intestinal ansas to the sutured incision (group B) occurred in five cases and the major omentum adhesion occurred in all animals. In the group A (adhesive) it occurred adherences of the major omentum in three cases. The microscopy of the hepatic incision repaired with the use of fibrin showed that the inflammatory infection is less intense, not associated with the formulation of secretion in the abscesses, and therefore has a more favorable later cicatricial aspect than a conventional suture with surgical thread.
\end{abstract}

Conclusion: In agreement with other biomedical literature works, the fibrin adhesive is a viable option for the performance of hemostasis in a animal model (rabbit) with severe hepatic injury.

Key words: Liver. Fibrin Tissue Adhesive. Sutures Techniques.

\section{RESUMO}

Objetivo: Avaliar o desempenho do adesivo de fibrina e do fio de sutura absorvível no reparo de lesões hepáticas provocadas em coelhos. Métodos: Coelhos $(n=16)$,Nova Zelândia, albinos, machos e fêmeas, 5 a 6 meses de idade, peso médio de 2500 gramas, foram distribuídos aleatoriamente em Grupo A(n = 8) - adesivo biológico e Grupo B(n=8) - fio de sutura. Após anestesia com acepromazina (1mg/Kg), quetamina (50mg/Kg) e fentanylEV (0,5ml/Kg), realizou-se laparotomia mediana supra-umbilical, o lobo hepático médio foi isolado e submetido a uma lesão padronizada grave. No grupo A foi aplicado o adesivo de fibrina. No grupo B as bordas da lesão foram suturadas com categute 4-0 simples, em pontos separados. Avaliou-se o tempo total de procedimento, tempo de hemostasia e volume da hemorragia. No $21^{\circ}$ dia de pósoperatório avaliou-se a presença de aderências e sinais de infecção na cavidade e procedeu-se a ressecção do lobo hepático médio para a avaliação histológica. Resultados: A média e desvio-padrão calculados mostraram que o tempo de procedimento, tempo de hemostasia e quantidade de sangramento foram significantes menores no grupo de animais submetidos ao uso do adesivo de fibrina. A extensão da ferida operatória foi significativamente maior nos animais do grupo sutura (média de 6,8cm) em relação ao grupo adesivo (média de 3,8cm) assim como o número de vezes da ocorrência de abscessos. A aderência de alças intestinais à lesão suturada (grupo B) ocorreu em 5 casos e adesão do omento maior ocorreu em todos os animais. No grupo A (adesivo) foram observadas aderências do omento maior em três casos. A microscopia da lesão hepática reparada com o uso de fibrina mostrou que a reação inflamatória é menos intensa, não está associada à formação de secreção ou abscessos e com isso tem um aspecto cicatricial tardio mais favorável que uma sutura convencional com fio cirúrgico. Conclusão: Em concordância com outros trabalhos da literatura biomédica, o adesivo de fibrina é uma opção viável para realizar hemostasia em um modelo animal (coelho) com lesão hepática grave.

Descritores: Fígado. Adesivo Tecidual de Fibrina. Técnicas de Sutura 


\section{Introduction}

Intra-abdominal hemorrhages from the hepatic or splenic trauma are severe and persistent ${ }^{1}$. The surgical procedure used for the control of the bleeding can be chosen between: selective individual control of the bleeding vessels, compression of injure, mass ligature of the injured parenchymal tissue, partial resection of the organ, coagulation with electric scalpel, haemostatic sponges or application of topic haemostatic agents (collagen, gelatin or cellulose) $)^{1,2,3}$. One non-surgical alternative is the procedure involving the transfusion of haemoderivates ${ }^{1,3}$. Recently, the use of fibrin adhesive has demonstrated success in the hemostasis of injures of parenchymal organs, especially the liver and the spleen. Topic application of the fibrin adhesive has obtained success in the treatment of superficial injures and capsular avulsion. Injection of fibrin adhesive on the inside of the wound basis and its surrounding tissue has presented an effective control of hemorrhage in the deep parenchymal injury. The additional advantage is that the action mechanism of the adhesive does not depend of intrinsic factors of coagulation of the host ${ }^{4,5,6,7}$. However, the use of adhesive in severe injury of parenchymal organs with intense hemorrhage still needs a standard protocol that can make its use more secure and effectiveness ${ }^{7.8 .9}$. This research has tried to evaluate the haemostatic capacity of the biological adhesive in an animal model with severe hepatic trauma, comparing it to the results of the use of a conventional suture thread.

\section{Methods}

The procedures of the PIBIC project (Institutional Program of Grants for Scientific Initiation - CNPq) were evaluated and approved by the Ethics Committee of the São Paulo Hospital - Federal University of São Paulo Escola Paulista de Medicina UNIFESP - (EPM). Sixteen albino rabbits (Oryctolagus cuniculus), males and females, six months old and with average weight of 2500 $\mathrm{g}$, were randomly distributed in group $\mathrm{A}(\mathrm{n}=8)$ with approximation of the edges of the standard hepatic incision with fibrin glue and group $B(n=8)$ suture of the hepatic standard incision with surgical thread. Anesthesia: the rabbits received as pre-anesthesic medication $(1 \mathrm{mg} / \mathrm{Kg})$ of acepromazine IM in the posterior region of the hip, and after twenty minutes received as anesthesic medication ketamine $(50 \mathrm{mg} / \mathrm{Kg}$ ) and fentanyl $(0,5 \mathrm{ml} / \mathrm{Kg})$, with spontaneous breathing. It was performed a supra-umbilical median laparotomy of $5 \mathrm{~cm}$ and identified the hepatic lobes, being the median hepatic lobe isolated over sterile gauze and subjected to a V incision of $2 \mathrm{~cm}$ height and $2 \mathrm{~cm}$ deep. In the animals of group A the injure edges were approximated with simple 4-0 catgut suture, in separated stitches. Sterile gauzes were used, straight after the incision and during synthesis, to absorb the bleeding and measure it. In the group $\mathrm{B}$, according to the manufacturer indication, it was applied $2.0 \mathrm{ml}$ of biological adhesive inside the incision at the same time of the approximation of the edges, keeping them together for the needed time to occur the hemostasis and formation of stable coagulum. It was evaluated the time of procedure (from the beginning of laparotomy to the end of bleeding) and the hemostasis time (from the beginning of incision to the end of bleeding). The bleeding was quantified based on the variation of weight of the gauze used to isolate and absorb the bleeding of the hepatic lobe during the standard trauma and its haemostatic manipulation. Histological evaluation: in the $21^{\text {st }}$ post-operative day the animals were subjected to euthanasia and evaluation macroscopically for the presence of adherences or abdominal sepsis. The median hepatic lobe was sent to histological analysis for the evaluation of the regeneration or healing hepatic process. Statistic study: it was established a p d" 0.05 for rejection of nullity hypothesis for the mean and standard deviation and the Student T-test.

\section{Results}

There were no animal deaths in the adhesive group and one in the suture group due to peritonitis on the $20^{\text {th }}$ post-operative day. The calculated mean and standard deviation showed that the procedure time, hemostasis time and bleeding quantity were significantly less in the group subjected to the use of fibrin adhesive (Table 1). The abdominal incision was significantly more extensive in the animals of the suture group (average $6.8 \mathrm{~cm}$ ) in relation to the adhesive group (average $3.8 \mathrm{~cm}$ ), as well as the number of occurrences of abscesses (Table 2). The intestinal adherence to the sutured incision (group B) occurred in 5 cases and adhesion of the major omentum occurred in all animals. In the group A (adhesive) adherences of the major omentum occurred in three cases (Table 2). The macroscopic observation characteristic of the animals of suture group showed a more extensive abdominal incision, intra-hepatic inflammatory reaction of the exsudative kind involving the suture thread which was missing or minimal in the animals of the group with the use of adhesive (Figure 1). The microscopic evaluation of the animals from group B (suture) showed in the injury region an inflammatory process involving thread fragments, followed by suppuration, necrosis with presence of great quantity of polymorphonuclears and minor fibroblastic proliferation (Figure 2). In the animals of group A (adhesive) the region was cleaner with inflammatory process of the foreign body type involving amorphous and eosinophilic material, with many giant cells and accentuated fibroblastic proliferation (Figure 3). 
TABLE 1 - Distribution of total procedure time (in minutes), hemostasis obtainment time (in seconds) and quantification of bleeding (in grams of blood in the gauze) in the groups A (adhesive) and B (suture)

\begin{tabular}{|c|cc|cc|cc|}
\hline & \multicolumn{2}{|c|}{ Procedure Time } & \multicolumn{2}{c|}{ Hemostasis Time } & \multicolumn{2}{c|}{ Bleeding Quantity } \\
\hline & Group A & Group B & Group A & Group B & Group A & Group B \\
\hline Rabbit 1 & 30 & 22 & 60 & 210 & 1,24 & 1,27 \\
\hline Rabbit 2 & 22 & 26 & 60 & 275 & 0,70 & 2,28 \\
\hline Rabbit 3 & 19 & 24 & 75 & 215 & 0,47 & 1,12 \\
\hline Rabbit 4 & 26 & 32 & 150 & 125 & 2,24 & 1,24 \\
\hline Rabbit 5 & 21 & 37 & 120 & 110 & 0,55 & 1,30 \\
\hline Rabbit 6 & 19 & 26 & 120 & 120 & 1,07 & 0,99 \\
\hline Rabbit 7 & 09 & 35 & 20 & 247 & 0,82 & 0,85 \\
\hline Rabbit 8 & 12 & 26 & 35 & 150 & 0,59 & 0,63 \\
\hline & & & & & & \\
\hline Mean & $\mathbf{1 9 . 7 5 *}$ & $\mathbf{2 8 . 5}$ & $\mathbf{8 0 * *}$ & $\mathbf{1 8 1 . 5}$ & $\mathbf{0 . 9 6} *$ & $\mathbf{1 . 2 1}$ \\
\hline SD & $\mathbf{1 . 0 9}$ & $\mathbf{0 . 9 6}$ & $\mathbf{1 9}$ & $\mathbf{2 2 . 5}$ & $\mathbf{0 . 0 4}$ & $\mathbf{0 . 0 6}$ \\
\hline
\end{tabular}

* Procedure time mean $\mathrm{A}<\mathrm{B}$

** Hemostasis time mean significantly $\mathrm{A}<\mathrm{B}$

*** Bleeding quantity mean significantly $\mathrm{A}<\mathrm{B}$

TABLE 2 - Distribution of occurrence of abscess (semi-quantitative evaluation) and of the extension (in millimeters) of the cicatricial fibrosis process and presence of adherence in groups A (adhesive) and B (suture)

\begin{tabular}{|c|cc|cc|cc|}
\hline & \multicolumn{2}{|c|}{$\begin{array}{c}\text { Occurrence of } \\
\text { abscess }\end{array}$} & \multicolumn{2}{c|}{ Cicatricial Fibrosis } & \multicolumn{2}{c|}{ Adherences } \\
\hline & Group A & Group B & Group A & Group B & Group A & Group B \\
\hline Rabbit 1 & $(-)$ & $(-)$ & 5.5 & 7.30 & $(-)$ & $(+)$ \\
\hline Rabbit 2 & $(+)$ & $(+)$ & 0.21 & 5.71 & $(+)$ & $(+)$ \\
\hline Rabbit 3 & $(-)$ & $(-)$ & 1.10 & 5.20 & $(-)$ & $(+)$ \\
\hline Rabbit 4 & $(-)$ & $(-)$ & 0.80 & 4.50 & $(+)$ & $(+)$ \\
\hline Rabbit 5 & $(-)$ & $(++)$ & 0.10 & 5.01 & $(-)$ & $(++)$ \\
\hline Rabbit 6 & $(-)$ & $(+++)$ & 0.10 & 6.30 & $(-)$ & $(+++)$ \\
\hline Rabbit 7 & $(-)$ & death & 6.30 & death & $(-)$ & death \\
\hline Rabbit 8 & $(-)$ & $(+++)$ & 5.50 & 0.50 & $(+)$ & $(+++)$ \\
\hline & & & & & & \\
\hline Mean & & & $\mathbf{1 . 6 0 *}$ & $\mathbf{1 2 . 8 5}$ & & \\
\hline SD & \multicolumn{7}{|r|}{} & $\mathbf{0 . 2 3}$ & $\mathbf{2 . 2 5}$ & & \\
\hline
\end{tabular}

The occurrence of abscesses was more frequent in group $\mathrm{B}$ than in group A.

* Fibrosis extension mean significantly $\mathrm{B}>\mathrm{A}$

The occurrence of adherence was more frequent in group $B$ than in group $A$.

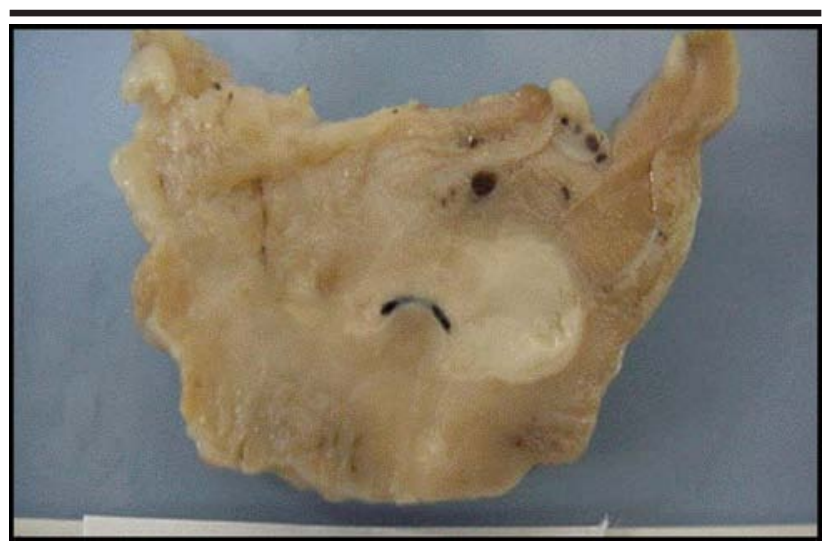

FIGURE 1 - Photography of an animal of Control Group noting the distance of the edges and exit of secretion from the inside of the operative wound 


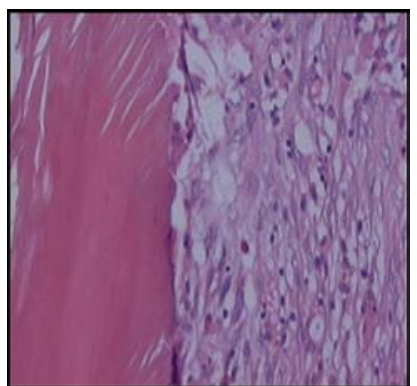

I

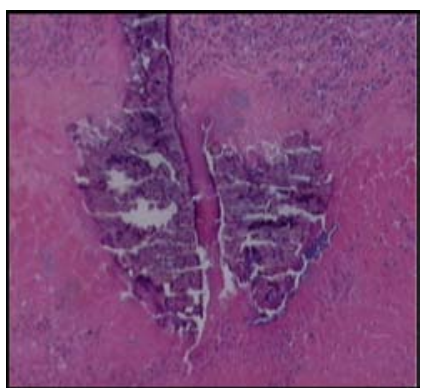

II

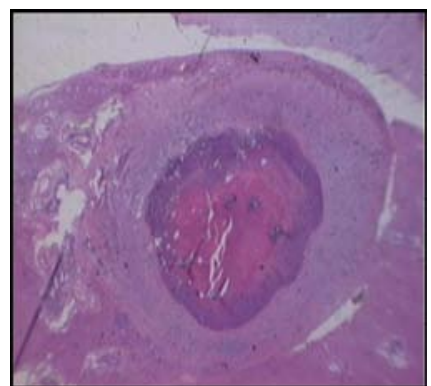

III

FIGURE 2 - Photomicrography of the animals of group B (suture). I - Healing area with abscess involving fragment of catgut (40x zoom, HE). II - Presence of remains of catgut with necrosis and polymorphonuclear inflammatory reaction (200x zoom, HE). III - Catgut with necrosis and suppuration (200x - HE)

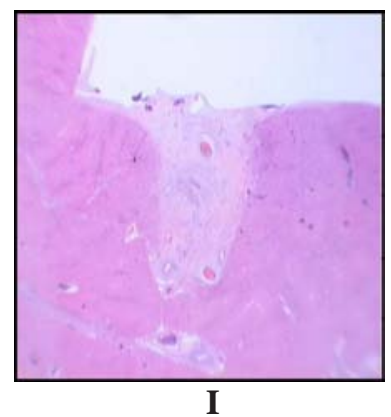

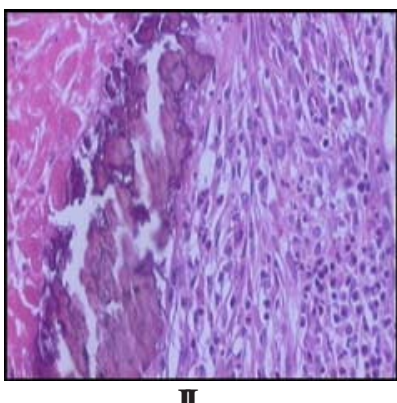

II

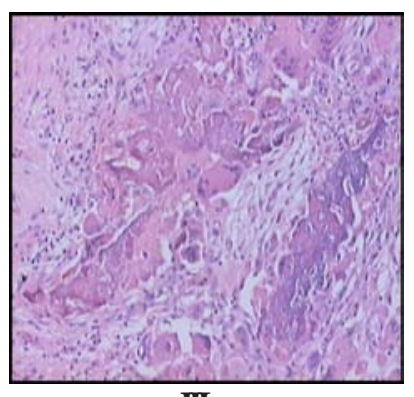

III

FIGURE 3 - Photomicrography of the animals of group A (adhesive). I. “Clean” injure location and approximated edges (40x zoom, HE). II - presence of non-absorbed adhesive involved by fibrosis (200x - HE). III - Inflammatory area with fibrosis and inflammatory process of the foreign body type to the amorphous material - biological adhesive (100x - HE)

\section{Discussion}

The fibrin adhesive is a natural adhesive that doubles and raises the final normal coagulation stage. In the presence of calcium chloride, the fibrin monomer is formed with the fibrinogen and mixed with thrombin, transformed in a thick fibrin polymer in the presence of a cryoprecipitate which contains the factor XIII of coagulation. The great part of the resistance obtained by the adhesive is obtained in the five initial minutes, but the adhesive remains with its resistance up to some hours ${ }^{5,6,7}$. The use of adhesives in hepatic bleeding has been researched as a hemostasis alternative in severe traumatic injury with associated wounds, in traumatic injury which videoassistence surgery and on transparietal biopsies in patients with coagulation deficiencies ${ }^{10,11}$. Experimental studies in pigs, dogs and rats contributed for a safer and more efficacious use of this therapeutic resource $\mathrm{e}^{10,11,12,13,14}$. This research attempted to make an experimental model in rabbits producing a standardized wound, which was established from the study of a pilot group. The chosen area and profundity of the wound were the ones which, if no haemostatic procedure were used, would lead to a bleeding which would persist for ten minutes or more. The majority of animals with this kind of injury presented important hemodynamic alterations and about $80 \%$ evolved to death, thus characterizing severe injury. The application of the fibrin adhesive was performed inside the incision, which was kept compressed by the minimal time for its polymerization and then verified the possibility of definitive removal of compression, while in the control group the injury was subjected to the conventional procedure of 4.0 catgut sutures. The results showed that the time for achievement of safe hemostasis was significantly less in the animals with use of adhesive, which also had a reduced surgical time. The amount of blood, measured by the weighing of the gauze used to cover and dry the hemorrhage was also significantly smaller with the use of adhesive. More efficient hemostasis and smaller surgical time were also obtained in heparinized rabbits subjected to the section of median auricular artery ${ }^{15}$. Videoassistence surgery application of fibrin in severe liver injures of dogs showed that the procedure time was reduced and the mortality in the control group was of $63 \%$ against no deaths in the adhesive group ${ }^{16}$. In a model in pigs subjected to a complex hepatic incision not only the operative time was lesser than in the control group but the necessity of infusion liquids was smaller to keep the hemodynamic stability of the animals $^{12}$. On another model on pigs with a severe injury (grade V) associated dilutional and hypothermic coagulopathy the fibrin led to a quicker control of the hemorrhage, diminishing of the necessity of reposition liquids and raised the survival ${ }^{3,9,17}$. Research in human beings with coagulopathy and subjected to percutaneous hepatic biopsy the fibrin adhesive showed itself to be useful in the control of hemorrhage ${ }^{14,18}$. Also in humans the use of selective laparoscopy and fibrin effectively reduced the laparotomy rate in a group of trauma by hepatic contusion and monitored at first in a non-operative manner ${ }^{8}$. The findings of this research agree with mentioned researches in biomedical literature showing that the model used in rabbits can be amplified to studies of other adhesives and/or deepen the study of fibrin glue. The macroscopic and microscopic aspects of the hepatic incision which were repaired with the use of fibrin showed that the inflammatory reaction is less intense and not associated with the secretion formation or 
abscesses, thus having a more favorable later cicatricial aspect than a conventional suture. Others works demonstrated that in the "in vitro" and "in vivo" evaluations the capacity of inflammatory reaction of the adhesive is tenuous and less intense than other adhesives or suture materials ${ }^{19,20,21}$. In model using rats, comparing fibrin to synthetic adhesive, it was demonstrated that the inflammatory reaction is less intense and the proliferation of collagen, which gives resistance to the scar, is more exuberant ${ }^{22}$.

\section{Conclusion}

The study has demonstrated that, in agreement with other works in biomedical literature, the fibrin adhesive is a viable option for the performance of hemostasis in an animal model (rabbit) with severe hepatic injury.

\section{References}

1. Cohn SM, Cross JH, Ivy ME, Feinstein AJ, Samotowka MA. Fibrin glue terminates massive bleeding after complex hepatic injury. J Trauma.1998; 45(4):666-72.

2. Uranüs S, Mischinger HJ, Pfeifer J, Kronberger L, Rabl H, Werkgartner G, Steindorfer P, Kraft-Kirz J. Hemostatic methods for the management of spleen and liver injuries. World J Surg.1996; 20(8):1107-11.

3. Holcomb JB, Pulsateri AE. Dry fibrine dressings reduce blood loss, resuscitation, volume, and improves survival in hypothermic coagulopathic with grade $\mathrm{V}$ liver injuries. J Trauma. 1999; 47:233-40.

4. Fagundes DJ, Taha MO, Monteiro Souza EF. Condutas em cirurgia: adesivos em cirurgia. São Paulo: Editora Atheneu; 2001.

5. Souza M, Fagundes DJ, Gomes PO, Ascenção AM, Guimarães CA, Mendonça Jr ITM, Guimarães AC, Martins VL. Fios de sutura: uma revisão histórica. Rev Ciênc Biol Saúde. 2001;2(1):98-100.

6. Fagundes DJ, Taha MO, Rivoire HC. Adesivos cirúrgicos: revisão e atualização. J Bras Med. 2002;82(3):101.

7. Biondo-Simões MLP, Tenius FP, Cavazana WC, Adur RC, Santos ARL, Colaço LM. Uso de adesivo em trauma hepático: estudo experimental em ratos. Acta Cir Bras. 1998; 8(1):24-7.

8. Chen RJ, Fang JF, Lin BC, Hsu YB, Kao JL, Kao YC, Chen MF. Selective application of laparoscopy and fibrin glue in the failure of nonoperative management of blunt hepatic trauma. J Trauma. 1998; 44(4):691-5.
9. Holcomb JB, McClain JM, Pusateri AE, Beall D, Macaitis JM, Harris RA, MacPhee MJ, Hess JR. Fibrin sealant foam sprayed directly on liver injuries decreases blood loss in resuscitated rats. J Trauma. 2000; 49(2):246-50.

10. Jackson MR, MacPhee MJ, Drohan WN, Alving BM. Fibrin sealant: current and potential clinical applications. Blood Coagul Fibrinolysis. 1996; 7(8):737-46.

11. Holcomb JB, Pulsateri AE, Hess JR, et al. Implications of new dry fibrine sealant technology of trauma surgery [ review ]. Surg Clin North Am. 1997; 77 : 943-52.

12. Cohn SM, Cross JH, Ivy ME, et al. Fibrine glue terminates massive bleeding after complex hepatic injury. J Trauma. 1998; 45: 666-72.

13. Davidson BR, Burnett S, Javed MS, Seifalian A, Moore D; Doctor N. Experimental study of a novel fibrin sealant for achieving haemostasis following partial hepatectomy. Br J Surg. 2000; 87(6):790-5.

14. Falstrom JK, Moore MM, Caldwell SH, Matsumoto AH, Abbott RD, Spotnitz WD. Use of fibrin sealant to reduce bleeding after needle liver biopsy in an anticoagulated canine model: work in progress. J Vasc Interv Radiol. 1999; 10(4):457-62.

15. Krishnan LK, Mohanty M, Umashankar PR, Lal AV. Comparative evaluation of absorbable hemostats: advantages of fibrin-based sheets. Biomaterials. 2004; 25(24):5557-63.

16. Salvino CK, Esposito TJ, Smith DK, Jacobs HK, Candel AG, Dries D, Gamelli R. Laparoscopic injection of fibrin glue to arrest intraparenchymal abdominal hemorrhage: an experimental study. J Trauma. 1993; 35(5):762-6.

17. Albéniz Arbizu E, López San Román A, Garcia González M, Foruny Olcina JR, Garcia-Hoz Rosales F, Bárcena Marugán R, Plaza Palacios G Gil Grande. Fibrin-glue sealed liver biopsy in patients with a liver transplantation or in liver transplantation waiting list: preliminary results. Transplant Proc. 2003; 35(5):1911-2.

18. Edmonson MB. Foreign body reactions to dermabond. Am J Emerg Med. 2001; 19(3):240-1.

19. Dickneite G, Metzner H, Pfeifer T, Kroez M, Witzke G A. comparison of fibrin sealants in relation to their in vitro and in vivo properties. Thromb Res. 2003; 112(1-2):73-82.

20. Feinstein AJ, Varela JE, Cohn SM, Compton RP, McKenney MG. Fibrin glue eliminates the need for packing after complex liver injuries. Yale J Biol Med, 2001; 74(5):315-21.

21. Fontes CER, Taha MO, Fagundes DJ. Estudo comparativo do uso de cola de fibrina e cianoacrilato em ferimento de fígado de rato. Acta Cir Bras. 2004; 19(1): 37-42.

\section{Correspondence:}

Murched Omar Taha

Rua Botucatu 740

04023-900 São Paulo - SP Brazil

Phone:(55 11)-5576-4272
Conflict of interest: none Financial source: CNPq

Received: April 04, 2006

Review: May 11, 2006

Accepted: June 15, 2006

\section{How to cite this article:}

Taha MO, Rosa K, Fagundes DJ. The role of biological adhesive and suture material in rabbit hepatic injure. Acta Cir Bras. [serial on the Internet] 2006 Sept-Oct;21(5). Available from URL: http://www.scielo.br/acb. 